\title{
Translation, adaptation and validation of the Roland-Morris questionnaire - Brazil Roland-Morris
}

L. Nusbaum, J. Natour,

M.B. Ferraz and J. Goldenberg
Disciplina de Reumatologia, Escola Paulista de Medicina,

Universidade Federal de São Paulo, São Paulo, SP, Brasil

\section{Correspondence}

J. Natour

Disciplina de Reumatologia

EPM, UNIFESP

Rua Botucatu, 740

04023-900 São Paulo, SP

Brasil

Fax: + 55-11-5576-4239

E-mail: jnatour@ reumato.epm.br

Publication supported by FAPESP.

Received May 24, 2000

Accepted December 12, 2000

\section{Abstract}

The purpose of the present study was to translate the Roland-Morris (RM) questionnaire into Brazilian-Portuguese and adapt and validate it. First 3 English teachers independently translated the original questionnaire into Brazilian-Portuguese and a consensus version was generated. Later, 3 other translators, blind to the original questionnaire, performed a back translation. This version was then compared with the original English questionnaire. Discrepancies were discussed and solved by a panel of 3 rheumatologists and the final Brazilian version was established (Brazil-RM). This version was then pretested on 30 chronic low back pain patients consecutively selected from the spine disorders outpatient clinic. In addition to the traditional clinical outcome measures, the Brazil-RM, a 6-point pain scale (from no pain to unbearable pain), and its numerical pain rating scale (PS) (0 to 5) and a visual analog scale (VAS) (0 to 10) were administered twice by one interviewer (1 week apart) and once by one independent interviewer. Spearman's correlation coefficient (SCC) and intraclass correlation coefficient (ICC) were computed to assess test-retest and interobserver reliability. Cross-sectional construct validity was evaluated using the SCC. In the pretesting session, all questions were well understood by the patients. The mean time of questionnaire administration was 4 min and $53 \mathrm{~s}$. The SCC and ICC were $0.88(\mathrm{P}<0.01)$ and 0.94 , respectively, for the test-retest reliability and $0.86(\mathrm{P}<0.01)$ and 0.95 , respectively, for interobserver reliability. The correlation coefficient was $0.80(\mathrm{P}<0.01)$ between the PS and Brazil-RM score and 0.79 $(\mathrm{P}<0.01)$ between the VAS and Brazil-RM score. We conclude that the Brazil-RM was successfully translated and adapted for application to Brazilian patients, with satisfactory reliability and cross-sectional construct validity.

\section{Introduction}

The incidence of low back pain and its socioeconomic implications have led to the search for improved methods of diagnosis and treatment and especially assessment of
Key words

- Low back pain

- Disability

- Roland-M orrisquestionnaire

- Spine

.................... physical disability, which may be either temporary or permanent.

Several clinical parameters have been developed in order to evaluate different diseases and their varied consequences. In 1983, Roland and Morris (1) selected 24 state- 
ments from the complete (136 questions) Sickness Impact Profile (SIP) (2) according to their ability to evaluate disability as a result of low back pain, in addition to the phrase "because of my back", thus developing and validating a specific questionnaire for patients suffering from low back pain. The questionnaire is quick and easy to administer, takes five minutes on average, and can be readily scored. This questionnaire proved to be valid when Deyo and Centor (3) compared it to the complete SIP in 1986. Its quick and easy handling, besides its wide use in different studies carried out worldwide, have convinced us of the need to develop a version to be used in Brazil.

\section{Material and Methods}

\section{Translation}

The recommendations made by Guillemin et al. $(4,5)$ were followed in order to establish the cultural equivalence of the original English version of the Roland-Morris (RM) questionnaire (1).

Three teachers of the English language (all native English speakers) who worked independently from one another initially translated the questionnaire. This resulted in three different versions, which were later compared to produce the final consensual version in the Brazilian-Portuguese language (V1). This version was then given to three other translators, all fluent in English, who did not know of the existence of the original questionnaire, and were asked to translate V1 back into English. These three new versions were compared to each other and used to construct a consensual English version from the translation of the Brazilian questionnaire (back translation - V2). This new English version (V2) when compared to the original English version proved to be grammatically and semantically equivalent, thus allowing V1 to be accepted as the final version in the Brazilian-Portuguese language.

\section{Cultural equivalence}

Version V1 was administered by an interviewer to 30 patients admitted at the Spine Disorders Outpatient Clinic (Division of Rheumatology, Federal University of São Paulo, São Paulo, SP, Brazil). In this group the female/male ratio was $27 / 3$, mean age was 54.3 years, 10 patients were totally illiterate and 7 patients had not completed elementary school. All of these patients had been suffering from low back pain for at least 3 months, none of them had deficient neurological signs or any other disability, and none was seeking monetary compensation. All patients agreed to participate in the study. The main purpose of this study phase was to assess the general comprehension of the questions.

The only change in relation to the original was the format of the questionnaire. The original English version was designed as self-applicable, whereas it was decided that the best option for the Brazilian-Portuguese version would be reading the questionnaire out loud to the patient during a personal interview due to the rate of illiteracy among our patients. Thus, the phrase "when you read these statements" was changed to "when you listen to these statements", followed by the instruction to answer yes or no.

The statements could be understood and answered by at least $80 \%$ of the patients, thus proving to be easy to understand and culturally appropriate. The time required for the application of the questionnaire was measured in minutes and seconds with a digital chronometer.

\section{Reliability and convergent validity}

Once the cultural equivalence had been established, the questionnaire was administered by the interviewer to a new group of 30 patients at the same outpatient clinic on three occasions. This new group also had chronic low back pain. There were 26 female and 4 
male patients, with a mean age of 51.4 years. Eleven patients were totally illiterate. On the first occasion (visit 1: baseline visit), in addition to the RM questionnaire which generated score 1 ( 0 to 24$)$, the patient was introduced to a quantitative scale for pain - the visual analog scale (VAS 1) ranging from 0 to 10 , and a qualitative scale for pain - pain scale (PS 1), ranging from no pain at all to the pain is almost unbearable, also used for validation purposes by the authors of the original questionnaire. The PS 1 scale was later assigned numerical values: 0 for no pain, and 5 for almost unbearable pain (Appendix) for calculation purposes. The patients were also requested to bend forward, without bending their knees while in the upright position, and the distance between their fingertips and the floor was measured in centimeters (index 1). The patient was then instructed to return 7 days after the first interview in order to be re-assessed by the same interviewer (visit 2: 1-week visit with the same interviewer) originating score 2 , VAS 2, PS 2, index 2, and by a second interviewer (visit 3: 1-week visit with a different interviewer), originating score 3 . We decided to use this time interval because we assumed that patient clinical status will not change over a period of 7 days in the absence of a specific intervention.

Descriptive statistics were used to establish the demographic and clinical characteristics of the patients assessed. Spearman's correlation coefficient was used to evaluate the reliability and validity of the test. Values above 0.478 were considered statistically significant $(\mathrm{P}<0.01)$. The intraclass correlation coefficient (ICC) was also used to assess intra- and interobserver reliability.

\section{Results}

Appendices 1 and 2 show the final Brazilian-Portuguese version and the original English version of the RM questionnaire and the scale for pain with its corresponding numerical values.

Table 1 shows the clinical and demographic data resulting from the survey conducted with the first patient group during the translation and cultural equivalence phase. This group was predominantly composed of females, with an average score of 13.9 for the questionnaire. Table 1 also shows the clinical and demographic data obtained from the second patient group during the reliability and validation phase. In this second group, the average score was 14.5 for the questionnaire and the group was also predominantly composed of females, the data being obtained by the first and second interviewers during the patient's return visit 7 days later. During this phase, even though no treatment was suggested, the average score was 14.6 for the first interviewer and 14.3 for the second. Tables 2 and 3 show the numerical variables obtained by Spearman's correlation coefficient. We obtained $r=0.88$ for intra-observer reliability and $r=0.86$ for interobserver reliability. The following correlations were also calculated: 0.54 between score 1 and VAS $1,0.79$ between score 2 and VAS 2, 0.65 between score 3 and VAS 2, 0.76 between score 1 and PS $1,0.76$ between score 2 and PS 2 , and 0.60 between score 3 and PS 2. All of these correlations were statistically significant $(\mathrm{P}<0.01)$. Only the

Table 1 - Demographic and clinical data of patients included in the translation and validation process of the Roland-Morris (RM) questionnaire.

Finger to floor: Fingertip to floor distance; visit 1: baseline visit; visit 2: visit scheduled 1 week later with the same interviewer; visit 3: visit scheduled 1 week later with a different interviewer. VAS: Visual analog scale. ${ }^{*}$ Data are reported as means \pm SD for 30 patients per group.

\begin{tabular}{lcccc}
\hline Patient data & Translation stage & Visit 1 & Visit 2 & Visit 3 \\
\hline Females/males & $27 / 3$ & $26 / 4$ & $26 / 4$ & $26 / 4$ \\
Average age & $54.3 \pm 9.47$ & $51.4 \pm 14.5$ & $51.4 \pm 14.5$ & $51.4 \pm 14.5$ \\
RM score* & $13.9 \pm 5.44$ & $14.5 \pm 6.79$ & $14.6 \pm 7.52$ & $14.3 \pm 7.47$ \\
Pain VAS & $6.6 \pm 2.81$ & $6.9 \pm 3.25$ & $6.4 \pm 3.34$ & - \\
Time* & $4^{\prime} 53^{\prime \prime} \pm 1^{\prime} 5^{\prime \prime}$ & $4^{\prime} 03^{\prime \prime} \pm 31^{\prime \prime}$ & $3^{\prime} 51^{\prime \prime} \pm 27^{\prime \prime}$ & $3^{\prime} 27^{\prime \prime} \pm 27^{\prime \prime}$ \\
Pain scale* & - & $2.5 \pm 1.33$ & $2.27 \pm 1.36$ & - \\
Finger to floor* & - & $10.21 \pm 12.0$ & $10.63 \pm 12.0$ & -
\end{tabular}


Table 2 - Validity of the Brazilian-Portuguese version of the Roland-M orris (RM) scale: Spearman's correlation coefficient between measures applied for group validation at baseline and during the 1-week visit.

For abbreviations, see legend to Table 1.

\begin{tabular}{llcccc}
\hline & & RM score & Pain VAS & Pain scale & Finger to floor \\
\hline \multirow{4}{*}{ Visit 1 } & RM score & - & \multicolumn{2}{c}{ Visit 1 } \\
& Pain VAS & 0.54 & - & & \\
& Pain scale & 0.76 & 0.64 & - & \\
& Finger to floor & 0.24 & 0.23 & 0.37 & - \\
& & & & Visit 2 & \\
Visit 2 & RM score & - & & & \\
& Pain VAS & 0.79 & - & & - \\
& Pain scale & 0.76 & 0.94 & - & \\
& Finger to floor & 0.10 & -0.14 & 0.26 &
\end{tabular}

Table 3 - Reliability of the Brazilian-Portuguese version of the Roland-M orris (RM) scale: intra- and interobserver Spearman's correlation coefficient and intraclass correlation coefficients between measures applied for group validation.

For abbreviations, see legend to Table 1.

\begin{tabular}{|c|c|c|c|c|c|c|}
\hline & & \multicolumn{4}{|c|}{ Visit 2} & \multirow{2}{*}{$\frac{\text { Visit } 3}{\text { RM score }}$} \\
\hline & & RM score & Pain VAS & Pain scale & $\begin{array}{l}\text { Finger to } \\
\text { floor }\end{array}$ & \\
\hline \multicolumn{7}{|c|}{ Spearman correlation } \\
\hline \multirow[t]{4}{*}{ Visit 1} & RM score & 0.88 & & & & 0.68 \\
\hline & Pain VAS & & 0.50 & & & \\
\hline & Pain scale & & & 0.54 & & \\
\hline & Finger to floor & & & & 0.90 & \\
\hline Visit 2 & RM Score & & & & & 0.86 \\
\hline \multicolumn{7}{|c|}{ Intraclass correlation } \\
\hline \multirow[t]{4}{*}{ Visit 1} & RM score & 0.94 & & & & \\
\hline & Pain VAS & & 0.63 & & & \\
\hline & Pain scale & & & 0.69 & & \\
\hline & Finger to floor & & & & 0.97 & \\
\hline Visit 2 & RM score & & & & & 0.95 \\
\hline
\end{tabular}

correlations referring to fingertip-floor measurements and other indices were not statistically significant. The ICC was 0.94 for the intra-observer score and 0.95 for interobserver score in the second visit. The ICC was 0.63 between VAS 1 and VAS 2, 0.69 between PS 1 and PS 2 and 0.97 between index 1 and index 2.

\section{Discussion}

Lack of data concerning the characteristics of the measurements most frequently used for the assessment of clinical parameters in studies with patients suffering from low back pain has made it difficult to interpret and evaluate therapeutical interventions, as well as prognosis. For a more reliable overall assessment of patients suffering from back pain, new questionnaires are being proposed for the evaluation of different parameters concerning physical disability and its consequences on quality of life.

In 1983, Roland and Morris (1) pointed out the conflicting results obtained from clinical trials evaluating the efficacy of therapeutic measures when identical procedures were used. Among the difficulties encountered in the assessment of therapeutic intervention on low back pain there is the possibility of spontaneous improvement of pain, the difficulty in forming homogeneous groups of patients, in making an accurate diagnosis based on the reported symptoms and the traditional factors of evolution, such as presence or absence of physical signs and symptoms, healing or death. In their original paper the authors found a mean score of 11.4 and they considered scores over 14 to indicate significant disability. The reproducibility between the two sets of scores was 0.91 .

Our choice of the RM questionnaire was based on its simple presentation and scoring system, and its use in the various studies reported in the medical literature concerning patients suffering from low back pain. Other questionnaires such as the Oswestry one (6), although widely used, are more difficult to apply and take more time to complete. For a successful transcultural translation, care should be taken to use terms and expressions that make sense in the new language. Fortunately, in our study we did not need any adaptation because the original questionnaire only explores day to day actions and needs, except that we changed the form of 
presentation of the questions.

In 1986, Deyo (7) compared the RM questionnaire to the complete SIP and considered the RM to be more sensitive to change throughout patient follow-up and to be more reliable when compared to the physical aspects of SIP.

The option of altering the presentation of the questionnaire (the patients having the questionnaire read to them instead of the questionnaire being self-applicable) was due to the considerable number of illiterate patients seen at our spine disorders unit. The statements used in the Brazilian questionnaire proved to be easy to understand since no question was left unanswered by $94 \%$ of the patients. Therefore, no modifications were necessary concerning question formulation as was the case in the studies by Deyo (8) and Ferraz et al. (9) in 1984 and 1990, respectively. The French version of the RM (10) also did not require further adaptations. In the French study the mean score of the French version was 12.1, and the ICC between the two scores was 0.89 , with a 7 -day interval between interviews.

As regards to reliability and validity of the RM used and other parameters of clinical evaluation, the data obtained in the present study were compatible with the results of previous studies in which the RM was used. In 1986, Weinstein et al. (11) studied patients who had undergone chemonucleolysis and discectomy, and who were interviewed 10 years after the event for comparison of the RM to other parameters such as visual scale for pain (scores 0 to 100), and "pain thermometer" ranging from "absence of pain" to "almost unbearable pain", also taken from the original RM, and obtained correlated rates when the end-point was the analysis of improvement of pain and return to a normal work routine. The mean score was 8.19 for patients who were satisfied with the treatment applied and 14.01 for patients who were not satisfied. The correlation coefficient between the score and pain thermom- eter was 0.51 . In our study this coefficient was 0.76 .

In 1986, Deyo (7) applied the RM directly to the patients and compared the results to the questions appearing in the SIP, and the two measurements were found to be correlated. In that study, the average score obtained was 10.1 while in our survey the average score was 14.3.

In 1988, Lanier and Stockton (12) compared short-term (work days lost) and longterm (still disabled after 6 weeks of treatment) prognosis results in patients with acute mechanical low back pain using the RM and concluded that a three-point increase in questionnaire scores implied a worse prognosis for the resolution of the condition. During the first visit the mean score for the symptomatic patients was 11.8 and during the second visit, the mean score fell to 2.7 among the patients who had improved.

Hadler et al. (13) in 1987 and Klein and Eek (14) in 1990 used the RM to evaluate groups of patients undergoing manipulation and laser therapy, respectively. In the latter study the RM score was also correlated with the visual analog scale, and the mean score was 5.4, perhaps because the patients had no acute exacerbation of the chronic pain.

In 1991, Frymoyer et al. (15) published the consensus of several authors suggesting the use of the RM in therapeutic trials, among other measures, such as data obtained by physical examination and additional exams for the evaluation of physical disability and prognostic evolution of patients with chronic low back pain, and highlighted the need for reliable parameters particularly in multicenter studies.

In 1994, Stratford et al. (16) compared the RM scoring to other questionnaires like the Oswestry and Jan Van Breener Institute ones (17), finding the latter to be more sensitive to change through time. In that study the mean score was 11.8.

In conclusion, the original version of the RM questionnaire proved to be reliable and 
valid in studies involving patients with lumbago. The Brazilian-Portuguese language version of this questionnaire also proved to be reproducible and valid when applied to a universe of Brazilians suffering from low back pain. The sensitivity to change of the Brazilian-Portuguese version is currently being evaluated.

The Brazil-RM is the first and so far the only available specific low back pain questionnaire in Brazil, representing an important tool for low back pain patient evaluation, especially in clinical studies.

\section{References}

1. Roland M \& Morris R (1983). Study of natural history of low back pain. Part II: development of guidelines for trials of treatment in primary care. Spine, 8: 145150.

2. Bergner $M$, Bobbitt RA, Carter WB \& Gilson BS (1981). The Sickness Impact Profile: development and final revision of a health status measure. Medical Care, 19: 787-805.

3. Deyo RA \& Centor RM (1986). Assessing the responsiveness of functional scales to clinical change: analogy to diagnostic test performance. J ournal of Chronic Diseases, 39: 897-906.

4. Guillemin F (1995). Measuring health status across cultures. Rheumatology in Europe, 24 (Suppl 2): 102-103.

5. Guillemin F, Bombardier C\& Beaton D (1993). Cross-cultural adaptation of healthrelated quality of life measures: literature review and proposed guidelines. J ournal of Clinical Epidemiology, 46: 1417-1432.

6. Fairbank JCT, Couper J \& Davies J B (1980). The Oswestry low back disability questionnaire. Physiotherapy, 66: 271273.
7. Deyo RA (1986). Comparative validity of Sickness Impact Profile and shorter scales for functional assessment in low back pain. Spine, 11: 951-954.

8. Deyo RA (1984). Pitfalls in measuring the health status of Mexican Americans: Comparative validity of the English and Spanish Sickness Impact Profile. American J ournal of Public Health, 74: 569-573.

9. Ferraz MB, Oliveira LM, Araujo PMP, Atra E \& Tugwell P (1990). Cross-cultural reliability of the physical ability dimension of the Health Assessment Questionnaire. J ournal of Rheumatology, 17: 813-817.

10. Coste J , Parc J M, Leberge E, Delecoevillerie G \& Paolaggi J B (1993). Validation Française d'une échelle d'incapacité fonctionalle pour l'évaluation des lombalgies (EIFEL). Revue du Rhumatisme. Edition Française, 60: 335-341.

11. Weinstein J, Sprattik E, Lehman T, McNeill T \& Hena W (1986). Lumbar disc herniation - A comparison of the results of chemonucleolysis ND open discectomy after ten years. J ournal of Bone and J oint Surgery, 68-A: 43-54.

12. Lanier DC \& Stockton PAS (1988). Clinical predictor of outcome of acute episodes of low back pain. J ournal of Family Practice, 27: 483-487.

13. Hadler NM, Curts $P$, Gillips DB \& Sinnett $S$ (1987). Benefit of spinal manipulation as adjunctive therapy for acute low back pain: stratified controlled trial. Spine, 12: 703-706.

14. Klein RG \& Eek BJ (1990). Low energy laser treatment and exercise for chronic low back pain: Double blind controlled trial. Archives of Physical Medicine and Rehabilitation, 71: 34-37.

15. Frymoyer J W, Nelson RM, Spangfort E \& Waddell G (1991). Clinical tests applicable to the study of chronic low back disability. Spine, 16: 681-682.

16. Stratford PW, Binkley J , Solomon P, Gill C \& Finch $E$ (1994). Assessing change overtime in patients with low back pain. Physical Therapy, 74: 528-533.

17. Lankahorst GJ, Van de Stadt RJ \& Voglelaar TW (1982). Objectivity and repeatability of measurements in low back pain. Scandinavian J ournal of Rehabilitation Medicine, 14: 21-26. 
Appendix 1 - Original and Brazilian-Portuguese version of the Roland-Morris questionnaire.

Instructions:

Quando suas costas doem (When your back hurts), você pode encontrar dificuldade em fazer algumas coisas que normalmente faz (you may find it difficult to do some of the things you normally do).

Esta lista possui algumas frases que as pessoas tem utilizado para se descreverem quando sentem dores nas costas (This list contains some sentences that people have used to describe themselves when they have back pain). Quando você ouvir estas frases pode notar que algumas se destacam por descrever você hoje (When you hear them, you may find that some stand out because they describe you today). Ao ouvir a lista pense em você hoje (As you hear the list, think of yourself today). Quando você ouvir uma frase que descreve você hoje, responda sim (When you hear a sentence that describes you today, answer yes). Se a frase não descreve você, então responda não e siga para a próxima frase (If the sentence does not describe you, than answer no and go on to the next one). Lembre-se, responda sim apenas à frase que tiver certeza que descreve você hoje (Remember, answer yes only to the sentence if you are sure that it describes you today).

Phrases:

1. [ ] Fico em casa a maior parte do tempo por causa de minhas costas. I stay at home most of the time because of my back.

2. [ ] Mudo de posição freqüentemente tentando deixar minhas costas confortáveis. I change position frequently to try and get my back comfortable.

3. [ ] Ando mais devagar que o habitual por causa de minhas costas. I walk more slowly than usual because of my back.

4. [ ] Por causa de minhas costas eu não estou fazendo nenhum dos meus trabalhos que geralmente faço em casa.

Because of my back I am not doing any of the jobs that I usually do around the house.

5. [ ] Por causa de minhas costas, eu uso o corrimão para subir escadas.

Because of my back, I use a handrail to get upstairs.

6. [ ] Por causa de minhas costas, eu me deito para descansar mais freqüentemente.

Because of my back, I lie down to rest more often.

7. [ ] Por causa de minhas costas, eu tenho que me apoiar em alguma coisa para me levantar de uma cadeira normal.

Because of my back, I have to hold on to something to get out of an easy chair.

8. [ ] Por causa de minhas costas, tento conseguir com que outras pessoas façam as coisas por mim.

Because of my back, I try to get other people to do things for me.

9. [ ] Eu me visto mais lentamente que o habitual por causa de minhas costas.

I get dressed more slowly because of my back.

10. [ ] Eu somente fico em pé por períodos curtos de tempo por causa de minhas costas.

I only stand up for short periods of time because of my back.

11. [ ] Por causa de minhas costas evito me abaixar ou me ajoelhar.

Because of my back, I try not to bend or kneel down.

12. [ ] Encontro dificuldades em me levantar de uma cadeira por causa de minhas costas. 
I find it difficult to get out of a chair because of my back.

13. [ ] As minhas costas doem quase que o tempo todo.

My back is painful almost all the time.

14. [ ] Tenho dificuldade em me virar na cama por causa das minhas costas.

I find it difficult to turn over in bed because of my back.

15. [ ] Meu apetite não é muito bom por causa das dores em minhas costas.

My appetite is not very good because of my back pain.

16. [ ] Tenho problemas para colocar minhas meias (ou meia calça) por causa das dores em minhas costas.

I have trouble putting on my socks (or stockings) because of the pain in my back.

17. [ ] Caminho apenas curtas distâncias por causa de minhas dores nas costas.

I only walk short distances because of my back pain.

18. [ ] Não durmo tão bem por causa de minhas costas.

I sleep less well because of my back.

19. [ ] Por causa de minhas dores nas costas, eu me visto com ajuda de outras pessoas.

Because of my back pain, I get dressed with help from someone else.

20. [ ] Fico sentado a maior parte do dia por causa de minhas costas.

I sit down for most of the day because of my back.

21. [ ] Evito trabalhos pesados em casa por causa de minhas costas.

I avoid heavy jobs around the house because of my back.

22. [ ] Por causa das dores em minhas costas, fico mais irritado e mal humorado com as pessoas do que o habitual.

Because of my back pain, I am more irritable and bad tempered with people than usual.

23. [ ] Por causa de minhas costas, eu subo escadas mais vagarosamente do que o habitual. Because of my back, I go upstairs more slowly than usual.

24. [ ] Fico na cama a maior parte do tempo por causa de minhas costas.

I stay in bed most of the time because of my back.

Appendix 2 - Qualitative pain scale.

Escala de dor (pain rating scale)

Numerical pain rating scale

Dor quase insuportável (the pain is almost unbearable) 5

Dor muito forte (very strong pain) 4

Dor forte (quite strong pain) 3

Dor moderada (moderate pain) 2

Dor leve (mild pain) 1

Sem dor (no pain at all) $\quad 0$ 